PROF-1308

\title{
EARIY DIAGNOSIS OF HYPERTENSION WITH MOLECULAR GENETIC TECHNIQUES
}

\section{MISS. SABA RIAZ \\ B.Sc Medical Lab Technology \\ M.Sc Microbiology and Molecular Genetics.}

Ph. D Scholar. Microbiology and Molecular Genetics.

Department of Microbiology and Molecular Genetics, University of the Punjab,

Quaid-e-Azam Campus, Lahore

\section{MR. FARRAKH MEHMOOD ALVI}

Ph. D Scholar. Microbiology and Molecular Genetics. Department of Microbiology and Molecular Genetics, University of the Punjab. New Campus Lahore.

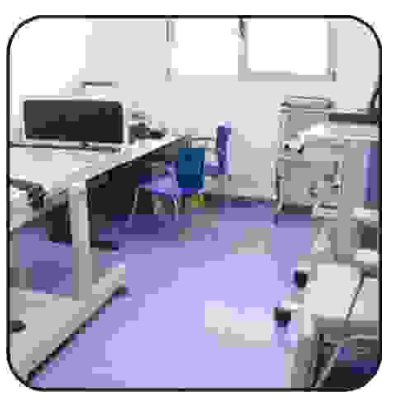

ABSTRACT... sabbb1502@yahoo.com. Objective: To standardize the molecular techniques for early diagnosis of genes of hypertension. Methodology and Results: These techniques include extraction of DNA in which we extracted DNA by manual method with results of high yield, less purity and it was more time consuming. On the other hand with kit (Fermentas) method yield was low with high purity and less time consuming. The purity of DNA was checked by spectrophotometer by using DNA/RNA ratio. Conditions for diagnosis was optimized for specific DNA sequence by using primers for genes Agt and Ace. Restriction digestion was done with the amplified product with restriction enzymes Lwel and Nco1 the result was found negative with no polymorphism. Single stranded conformational polymorphism (SSCP) was performed which is more efficient method of obtaining information about level of polymorphism with in anonymous nuclear loci than the restriction enzyme protocol. SSCP is also more specific because it gives idea which specific portion of gene is highly polymorphic. The result was again negative. Conclusion: This preliminary study of molecular analysis optimized the conditions for detection of polymorphism of candidate genes associated with hypertension. Following the same standardized conditions this is possible that we can study and diagnose thousands of hypertensive patients. This is very much helpful for future planning of persons who are prone to hypertension due to family history.

Key words: Molecular techniques, Hypertension, polymorphism. 


\section{INTRODUCTION}

Hypertension is an important public health challenge because it is associated with morbidity and mortality ${ }^{1}$ The cause of hypertension is "unknown" or essential in $90 \%$ of people and genetics within this group is thought to contribute $40 \%$ while environment (lifestyle) is $60 \%$. The remaining $10 \%$ is due to underlying disease; renal diseases, renal arterial stenosis, tumors (brain, lung, kidney, adrenal), endocrine and medications ${ }^{3}$ Research on the molecular genetics of human hypertension developed less than 15 years $\mathrm{ago}^{4}$. Its goal was to identify the loci involved, to detect gene variants at the loci identified, and associate them with intermediate phenotypes, and ultimately to estimate their quantitative effects on blood pressure and their interaction with the principal environmental factors $^{5}$. Gorzelniak et al ${ }^{7}$ shows that renin-angiotensin system genes are differentially regulated in human obesity and hypertension. The researches are concentrated on the genes encoding the components of renin angiotensin system (R-A): Which includes Angiotensinogen (AGT) M235T, angitesin1-coverting enzyme (ACE) G2350A, (ACE) I/D , angiotensinogen II type 1 receptor (ATR1) A1166C,and aldosterone synthase C-344T polymorphisms ${ }^{8}$. Now it is much easy to checkout the phenotype of patients due to expanded genotyping with the availability of a 300000 genomewide single-nucleotide polymorphism map ${ }^{9}$. Polymorphisms of candidate genes have been studied in association and linkage studies to assess their potential role in essential hypertension in humans ${ }^{10}$. Results investigation shows polymorphisms of the angiotensinogen (AGT) gene and the angiotensinconverting enzyme (ACE) gene in human essential hypertension is more common ${ }^{11}$. Due to importance of AGT and ACE with reference to hypertension we included these two genes in our study.

\section{MATERIALS AND METHODS}

Criteria for Collection of Blood Samples: Only those subjects were selected who already have history of hypertension. The study includes $50 \%$ subjects with essential hypertension and $50 \%$ normotensives (control). Normotensives also play a very important role for authenticity of genetic study that's why controls were also included in the study. Blood was drawn after an informed consent. Diagnosis of essential hypertension was made at Mayo Hospital Lahore

Sample Preparation: Whole blood was collected in EDTA tubes (Greiner). 200ml of fresh blood was used for DNA isolation in kit method and about $3 \mathrm{CC}$ for manual DNA extraction. Blood was aliquoted in $200 \mathrm{ml}$ portions and kept at $-200 \mathrm{C}$ in labeled tubes.

Genomic DNA Extraction: Manual method for Genomic DNA Extraction Following the procedure of Ponez et $\mathrm{al}^{13}$. Genomic DNA was also extracted by using kit Fermentas by following the manufacturer's instructions. Detection of Extracted DNA was done by Gel Electrophoresis following Sambrook ${ }^{12}$.

Spectrophotometry for DNA purity: Absorbance was taken at $260 \mathrm{~nm}$ and $280 \mathrm{~nm}$ by spectrophotometer (CECIL 7200). OD ratio 260/280 was calculated by using following formula ${ }^{12}$.

Concentration for DNA = Absorbance at $260 \mathrm{~nm} \times 50$ $\mathrm{mg} / \mathrm{ml}$

Concentration for Protein $=$ Absorbance at $280 \mathrm{~nm} \times 50$ $\mathrm{mg} / \mathrm{ml}$

Polymerase chain reaction (PCR): The Hypertension related genes were determined by polymerase chain reaction (PCR) amplification of genomic $\mathrm{DNA}^{12}$. The amplification of genes of interest primers was designed. PCR was performed in standard conditions determined for each amplification reactions using Eppendorf Master Thermal Cycler (Primus 96). Primers used in study were synthesized from GENE LINK. Primer used for

AGT gene was AGT18 F 5'GATGCGCACAAGGTCCTG-3' and AGT25R 5'-

CAGGGTGCTGTCCACACTGGCTCGC-3'. Primer used for ACE gene were ACE $2350 \mathrm{~F} 5$ 5 $^{-}$

CTGACGAATGTGATGGCCGC-3' and ACE 2350 R 5'TTGATGAGTTCCACGTATTTCG-3'. 
Digestion of DNA with Restriction Endonucleases: Pipette the following into a clean microcentrifuge tube: $5 \mathrm{ml}$ of amplified fragment $(0.2 \mathrm{mg})$ in TE buffer $1.5 \mathrm{ml}$ 10X restriction buffer (Fermentas), $1 \mathrm{ml}$ of restriction enzyme (Lwel, Ncol, Bsh1236l), Water to $7.5 \mathrm{ml}$. Restriction endonuclease (1 U/mg DNA) was added and incubates for 3 hours at the $37^{\circ} \mathrm{C}$. Stopped the reaction and prepared it for electrophoresis by incubating 10 minutes at $650 \mathrm{C}$. We used sample \# 4 two DNA samples were used one as control, which was just genomic DNA and other was amplified product of same sample For detection of restriction digestion electrophoresis was done by using agarose gel and results were visualized.

Single Stranded Conformational Polymorphism (SSCP): SSCP was performed by going through following steps. Preparation of the SSCP Gel Preparation of samples for SSCP Electrophoresis, Separation and Analysis of DNA fragments by SSCP
Gel Electrophoresis, Detection of Single Stranded Conformational Polymorphism (SSCP) by Silver Staining ${ }^{12}$.

\section{RESULTS AND DISCUSSION}

Subjects were examined clinically and their blood pressure was checked at the spot. Selection of patients was made depending of age, sex, family history of illness and rate of blood pressure. The age range of control was 45 plus which was ideal age for studying controls. It was shown that dietary restriction of salt has positive effects on a significant number of hypertensive patients ${ }^{2}$ Effectiveness of salt restriction in nonhypertensive individuals for the prevention of hypertension or associated cardiovascular diseases has been studied ${ }^{21}$. Figure (1) shows DNA samples run on agarose gel. 13 DNA preps were run all of them extracted manually but one sample $36 \mathrm{~F}$ where $F$ (Fermentas).

\section{Graphs:}
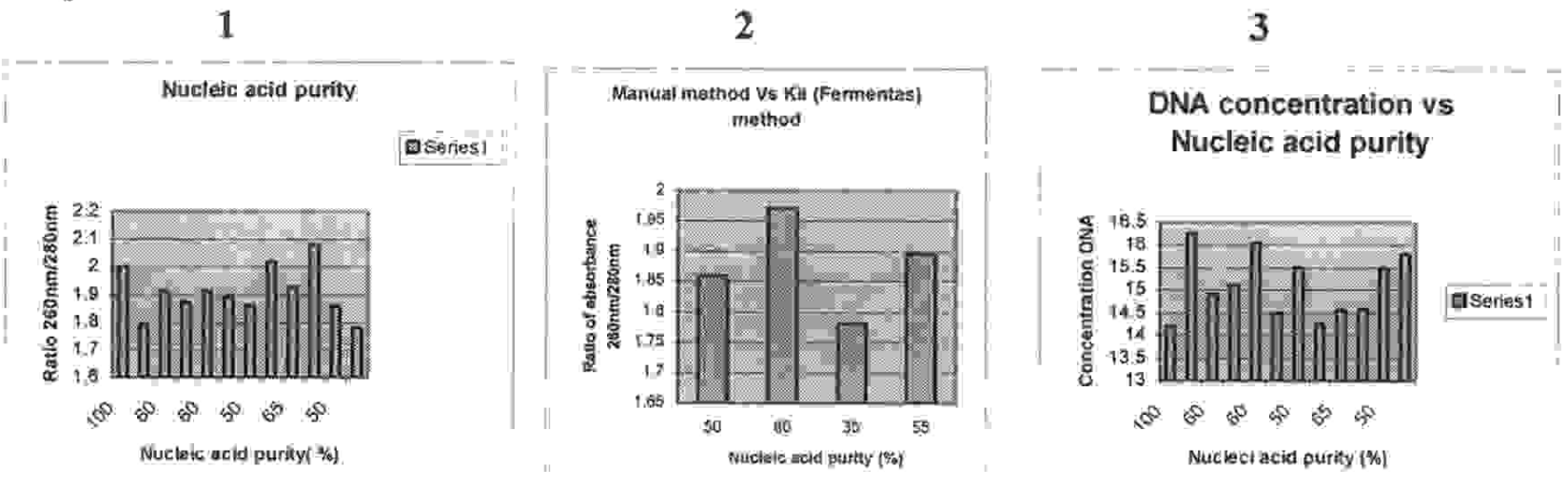

Graph 1: Nucleic acid purity vs absorbance of samples at $260 \mathrm{~nm}$

Graph 2: Comparison of extracted DNA by manual and kit (Fermentas) method. Graph 3: DNA concentration $(\mu \mathrm{g} \backslash \mathrm{ml})$ and Nucleic acid purity $(\%)$ 


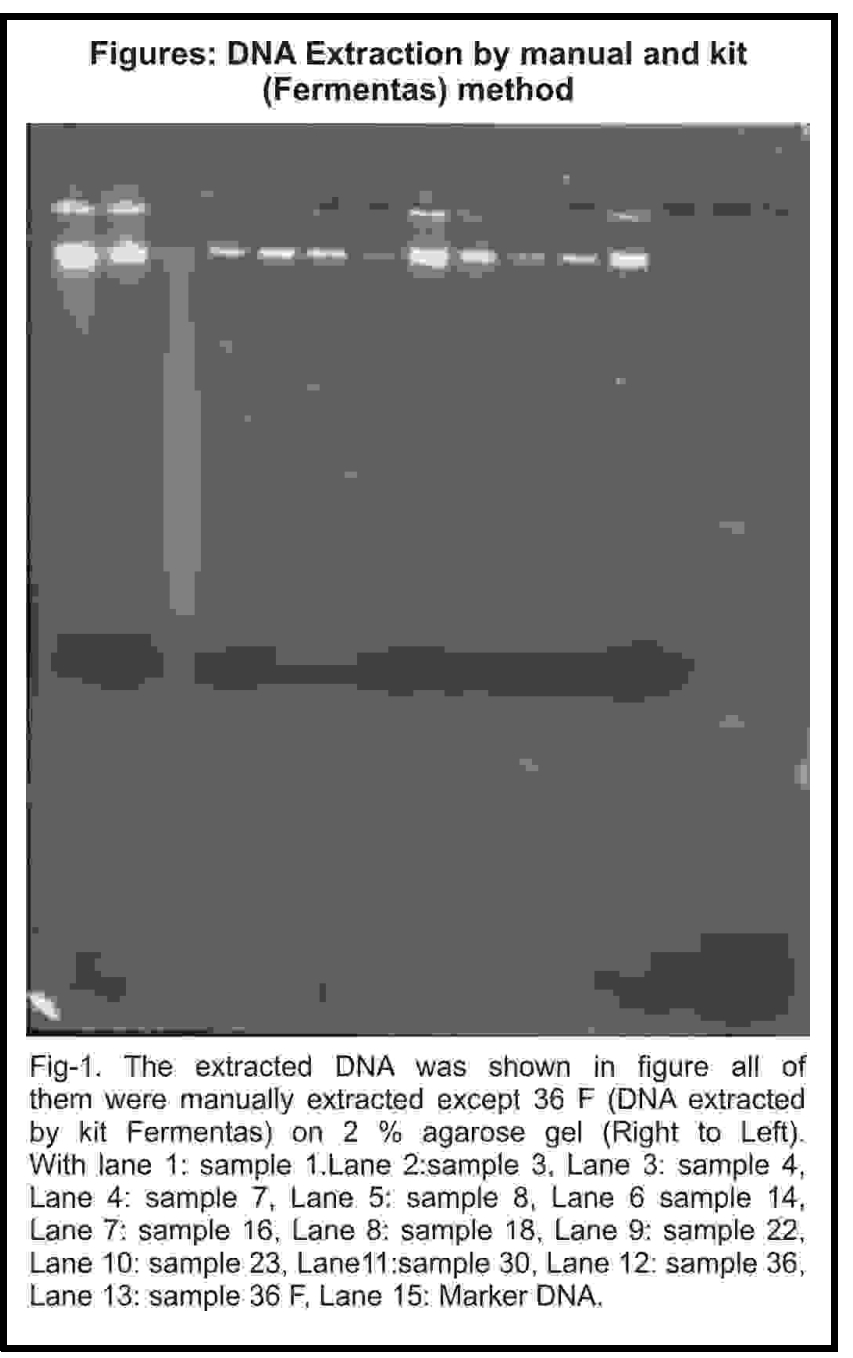

We run sample number 36 as manual extraction as well as kit method to compare the purity and yield of both methods of extraction. Taking ratio of absorbance at $260 \mathrm{~nm}$ and $280 \mathrm{~nm}$ we did the comparison of purity. This also showed that samples 1, 18, 23 were most pure DNA preps. Sample number 3 and sample number 36 had even less then $50 \%$ nucleic acid purity. Remaining all samples were more than $50 \%$ purity. We also calculated the concentration of DNA by using the formula. We concluded that sample 3 had most DNA concentration, which was $16.25 \mu \mathrm{g} / \mathrm{ml}$. While sample 1 had least DNA concentration that was $14.2 \mu \mathrm{g} / \mathrm{ml}$. Here the important point was that sample 1 was extracted by kit (Fermentas) method while sample 3 was extracted by manual method. Use of this spectrophotometer for $\mathrm{OD}_{260}: \mathrm{OD}_{280}$. Significant absorbance at $230 \mathrm{~nm}$ indicates contamination by phenolate ion, thiocyanates, and other organic compounds ${ }^{15}$. For many years, the ratio of the absorbance at $260 \mathrm{~nm}$ and $280 \mathrm{~nm}$ $\left(O D_{260}: O D_{280}\right)$ has been used as a measure of purity of isolated nucleic acids. This method dates from Warburg and Christian ${ }^{18}$ who showed that the ratio is a good indicator of contamination of protein preparation by nucleic acids ${ }^{16,18,19,20}$. We used bar chart to check out the purity of DNA preps. All samples were shown in graph (1) with their absorbance ratio along with their nucleic acid purity in percentage. As shown in graph that when absorbance ratio was near 2 it seems that samples were more pure because nucleic acid purity was $100 \%$. We compared the method of DNA extraction manual and kit (Fermentas) method. We used to compare yield DNA by these two methods and found that yield of DNA was higher in manual method this was cleared in figure (1) where sample 36 which was extracted manually run parallel with sample $36 \mathrm{~F}$ (Fermentas). It was shown that manual method showed more yield of DNA as compared to kit method. On the other hand for the purpose to check the purity we took absorbance of sample 16 manually extracted DNA, sample 36 manually extracted DNA, sample $16 \mathrm{~F}$ (In sample 16 DNA was extracted by kit Fermentas method) and sample $36 \mathrm{~F}$ (In sample 36 DNA was extracted by kit Fermentas method).

These results prooved that DNA extracted by manual method was less pure but with more concentration or yield as compared to DNA extracted by kit (Fermentas) that had more purity but less concentration of DNA. Comparison of both methods of DNA extraction (manual and kit fermentas) was also shown graphically in graph. Graphical representation of comparison proved that kit (method) extraction was more pure. Polymerase chain reaction (PCR) is a key procedure in modern molecular biology but may be adversely affected by many factors and it is difficult to optimize reaction conditions; a technically simple and effective method to set up an optimal PCR conditions is required. Uniform design (UD) is a method that enables many factors to be investigated ${ }^{23}$. The efficiency and specificity of amplification in PCR with Taq DNA Polymerase is highly dependent on the nature of the 
template DNA and primers. Therefore optimization of reaction conditions is often necessary. Because of the large number of variables $(\mathrm{pH}$, salt concentration and magnesium ions), these optimization experiments often take much time and effort.

\section{Optimization of conditions for AGT (gene)}

\section{$\begin{array}{llll}4 & 3 & 2 & 1\end{array}$}

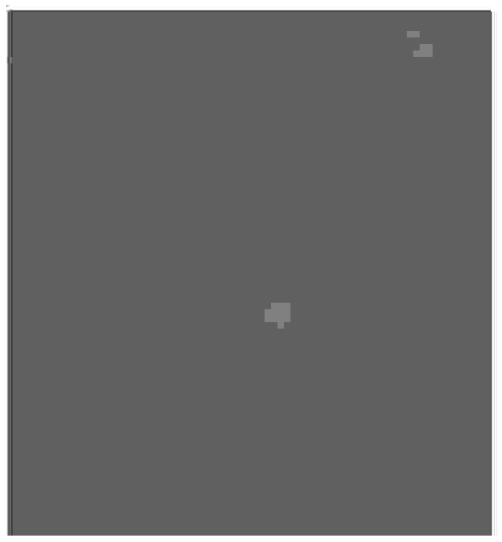

21

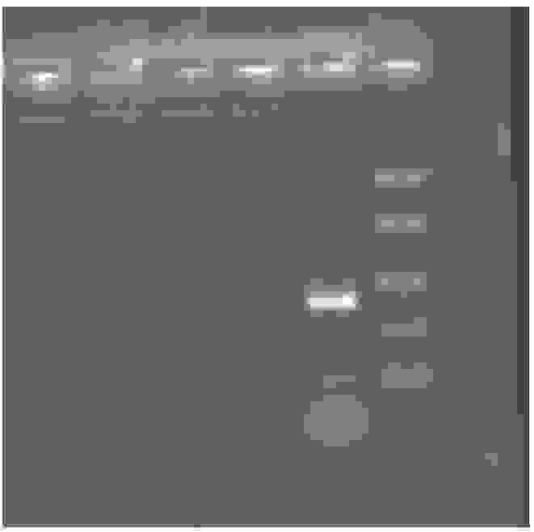

$11 \quad 109876 \quad 5 \quad 4321$

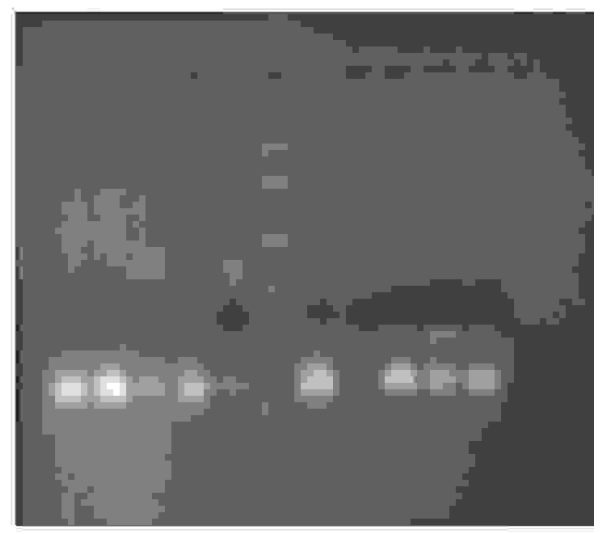

Fig-2. This figure is showing optimization of conditions for AGT gene. Lane 1:sample 7 at $61 \mathrm{C}$, Lane 2: sample 36 at $61 \mathrm{C}$, Lane 3: sample 1 at $52 \mathrm{C}$, Lane 4: sample 7 at $52 \mathrm{C}$, Lane 5 : sample 1 (With Triton X-100) at $50 \mathrm{C}$, Lane 6: DNA marker, Lane 7: sample 1 at 50 C, Lane 8: sample 1 (With Triton X-100) at 51 C, Lane 9: sample 1 at $51 \mathrm{C}$, Lane 10: sample 1 at $52 \mathrm{C}$ for 45 seconds, Lane 10: sample 1 at $52 \mathrm{C}$ for 1 minute (total 30 cycles each).

Fig-3. At temperature 53 C AGT gene was amplified. Lane 1: DNA marker, Lane 2; empty well, Lane 3: sample 8, Lane 4: sample 12.

Figure 4: $2 \%$ agarose gel showing confirmed optimized annealing temperature for AGT gene at $55 \mathrm{C}$. Lane 1: DNA marker, Lane 2: sample 7 amplified at 55C. Remaining wells were empty.

If a GC-rich template DNA is used, additives to the usual buffer are often required to obtain sufficient specificity of amplification. For this purpose, formamide, DMSO and glycerol, which facilitate ds DNA melting, are included in the Kits. One of such kit is PCR Optimization Kit of fermentas that contains $2 X$ PCR mix (Fermentas \# K 0171). PCR has a several qualitative characteristics such as specificity, efficiency (yield of product), sensitivity and fidelity (error rate). Figure (2) is showing almost all attempts that were used to optimize the conditions for PCR in case of AGT gene. We used two samples at $61{ }^{\circ} \mathrm{C}$ as annealing temperature for 25 cycles but with negative result because there was no amplification. We run PCR at annealing temperature of $50{ }^{\circ} \mathrm{C}$ results were positive with low yield. We added triton $\mathrm{X}-100$ in sample 1 that was run at $50{ }^{\circ} \mathrm{C}$. Triton $\mathrm{X}-100$ was detergent, which helps in the denaturation of two strands. We also run same sample 1 at same temperature that was $50{ }^{\circ} \mathrm{C}$ but without triton X-100 but with no amplification found. Then we run PCR at $51{ }^{\circ} \mathrm{C}$ both with triton $\mathrm{X}-100$ and without it but result showed that sample that contain triton $\mathrm{X}-100$ gave amplification while that sample that was with out triton $X-100$ was negative means no amplification. In figure (3) AGT gene was used to amplify at annealing temperature $53{ }^{\circ} \mathrm{C}$ without using 
detergent that was triton $X 100$. But important point was that both bands of sample 8 and sample 12 were showing smear like appearance that may be because of low temperature or non-specific priming.

\section{AGT gene amplified batch}

$$
\begin{array}{lllllllllllll}
13 & 12 & 11 & 10 & 9 & 8 & 7 & 6 & 5 & 4 & 3 & 2 & 1
\end{array}
$$

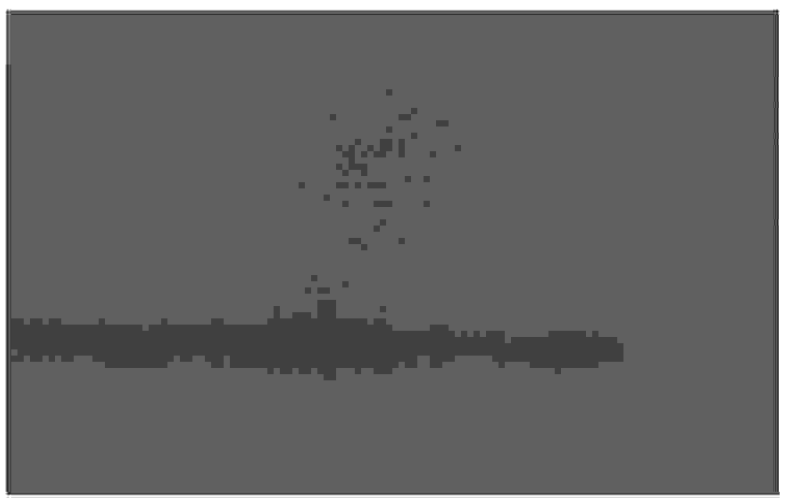

Figure 5: $2 \%$ agarose was used to visualize the amplified AGT gene at temperature $55 \mathrm{C}$. Lane 1: DNA marker, Lane 2: sample 1, Lane 3: sample 3, Lane 4: sample 4, Lane 5: sample 7, Lane 6: sample 8, Lane 7: sample 14, Lane 8: sample 16. Lane 9: sample 18, Lane 10: sample 22, Lane 11: sample 23, Lane 12: sample 30, Lane 13: sample 36

This gave idea to increase the annealing temperature in order to get specific amplified band instead of nonspecific priming. The other point that was cleared by this figure was that even without using detergent triton X-100 we can amplify the desired sequence of reasonable yield. PCR was run at annealing temperature of $55{ }^{\circ} \mathrm{C}$ with out detergent triton X-100 (Fig 4). Amplified band of good yield was obtained. This was the best optimized annealing temperature for amplification of AGT gene. The amplified product was $303 \mathrm{bp}$ that was obtained between the band of DNA marker of $200 \mathrm{bp}$ and $400 \mathrm{bp}$. Optimized batch shown in figure (5). Remaining wells had samples as sample 1 in lane 2and so on. Almost all samples amplified well with good yield except sample 14, 16, 30 and 36 . These samples showed less yield but they also amplified well. The amount of DNA added in PCR tube was also very important because when that amount was less then required good yield was not obtained but on the other hand when amount of DNA was ok that gave good yield. The final optimized condition for amplification of AGT gene was first denaturation $3 \mathrm{~min}$ at $94{ }^{\circ} \mathrm{C}$, second at $40 \mathrm{sec}$ at $94{ }^{\circ} \mathrm{C}$. There were two steps of polymerization first for $40 \mathrm{sec}$ at $72{ }^{\circ} \mathrm{C}$ and other was $5 \mathrm{~min}$ at $72{ }^{\circ} \mathrm{C}$. After completing amplification of AGT gene at optimized condition the next gene was ACE. In figure (6) there were three amplified samples.

\section{Optimization of conditions for ACE gene}
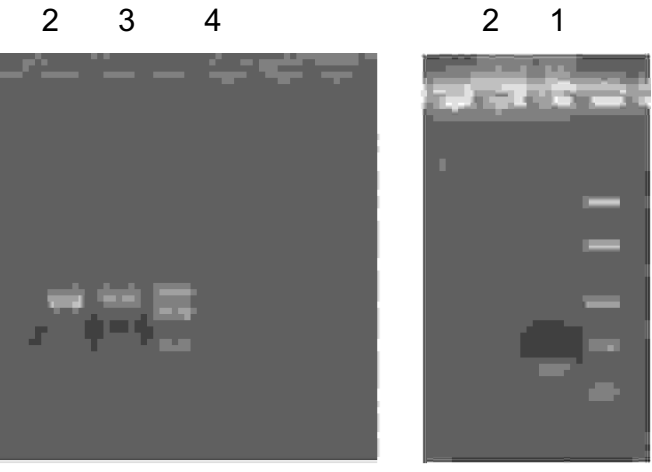

Fig-6. A $2 \%$ agarose gel was with annealing temperature of $55 \mathrm{C}$. The result showed that this annealing temperature was best for AGT gene amplification but not for ACE amplification because of many nonspecific priming yielding many bands of ACE gene amplification product. Lane 1: DNA marker, Lane 2: sample 16 amplified product of AGT gene, Lane 3: sample 36 amplified product of AGT gene, Lanes 4 : sample 14 amplified products of ACE gene but due to low annealing temperature showing many bands; which was result of nonspecific priming.

Figure 7: The final standard annealing temperature for ACE gene was $58 \mathrm{C}$. Lane 1: DNA marker, Lane 2: sample 4 amplified product of ACE gene

Two of them were amplified product of AGT gene and one of them was amplified product of ACE gene. In figure (7) we run PCR at annealing temperature of 58 ${ }^{0} \mathrm{C}$ with 30 cycles of amplification and result appeared satisfactory. There was no special chemical or reagent or any detergent was added. In ACE batch 1 and batch 2 figure $(8,9)$ DNA marker was run in lane 1 . Four samples (DNA preps) were also amplified using the same standard condition of amplification. 


\section{ACE gene amplified batch 1 and 2}
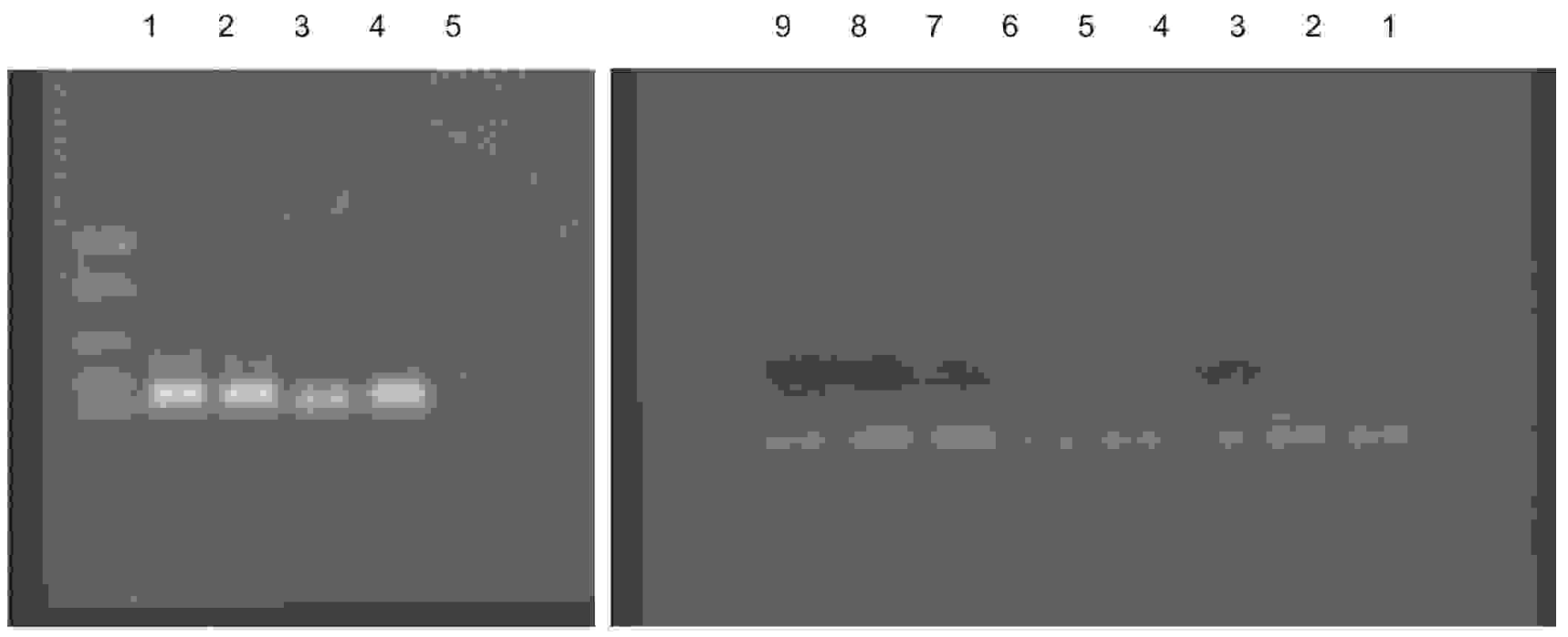

Figure 8: ACE gene amplified at $58 \mathrm{C}$ in batch 1. Lane 1: DNA marker, Lane 2: sample 1, Lane 3: sample 3, Lane 4: sample 4, Lane 5: sample 7.

Figure 9: This figure shows the 2 batch of ACE gene amplification. Lane 1: DNA marker, Lane 2: sample 14, Lane 3: sample 16, Lane 4: sample 30, Lane 5; sample 36, Lane 6: sample 8, Lane 7; sample 18, Lane 8: sample 22, Lane 9: sample 23.

These samples were sample number 1, 3, 4 and sample 7. Only PCR mix, primers and $5 \mu$ l of extracted DNA were added in reaction mixture. PCR was run at annealing temperature of $58{ }^{\circ} \mathrm{C}$ and 30 cycles of amplification. The steps involved for amplification of ACE gene were first denaturation at $94{ }^{\circ} \mathrm{C}$ for 3 minutes, next at $94{ }^{\circ} \mathrm{C}$ for $45 \mathrm{sec}$. In figure (10) amplified product of AGT gene was digested with enzyme $L$ wel. The results showed no polymorphism in any of the sample used. In well 1 DNA marker was loaded and from well 2 to well 8 all samples was loaded with the addition of restriction enzyme but they showed negative result with no polymorphism. Controls were run in well 9, 10 and 11. In lane 9 chromosomal DNA was digested by $L$ wel and it gave smear as result of complete digestion that means restriction enzyme was working ok. In case of lane 10 again chromosomal DNA was added but in that no restriction enzyme was added so this was negative control. Last lane 11 had amplified AGT product with no restriction enzyme so result was ok because that was again used as a negative control. Restriction digestion was used to check out the polymorphism. The optimization of technique was there but there was no polymorphism seen in amplified AGT products that was used in optimizing this technique. In Figure (11) another restriction enzyme was used to see the polymorphism T174. DNA marker was run along the sample to see the result. AGT amplified PCR product was used. In this figure (11) lane 2 to lane 8 amplified AGT products were used while in last three lanes that were lane 9 , lane 10 and lane 11 controls were present. In lane 9 there was positive control that had chromosomal DNA with restriction enzyme Nco1 but here in figure it showed that positive control was not worked that means that enzyme may not be working. Both negative controls as in case of lane 8 chromosomal DNA along with restriction enzyme Nco1 was negative. But because positive control was not giving correct result that's why we can assume that enzyme was not worked. 


\section{Restriction digestion with restriction enzyme Lwel}

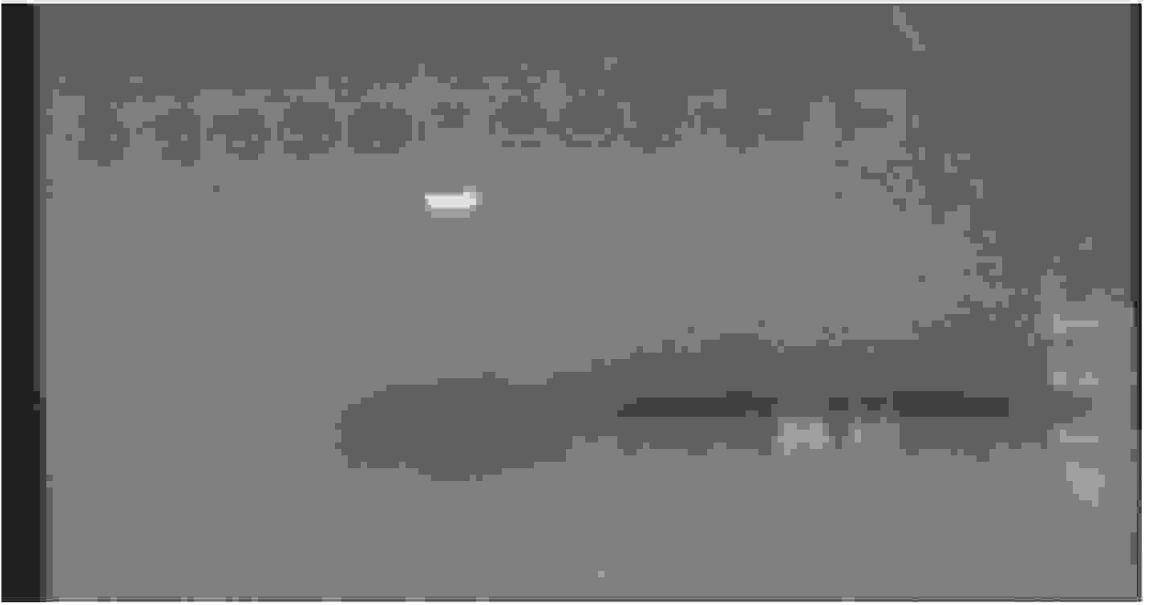

$11 \quad 10: 9 \quad 8 \quad 7 \quad 6 \quad 5 \quad 4 \quad 3 \quad 2 \quad 1$

Figure 10: The $2 \%$ agarose gel was showing restriction digestion with restriction enzyme L wel. Lane 1:DNA marker, Lane 2 sample 24, Lane 3: sample 16, Lane 4: sample 18, Lane 5: sample 22, Lane 6: sample 23, Lane 7: sample 30, Lane 8: sample 36, Lane 9:Chromosomal DNA digested with L wel, Lane 10: chromosomal undigested, Lane 11: sample 22 amplified as control.

The last lane 11 had amplified product of AGT but without restriction enzyme so it was the negative control of technique Single-stranded DNA when placed in a non-denaturing solution folds into a specific $2^{0}$ structure determined by its sequence. Strands differing by as little as 1 base can occupy different conformations. This is visualised by a difference in electrophoretic mobilities of the two strands. When SSCP started limitation and considerations of technique should be noticed to avoid any problem. Single-stranded DNA mobilities are dependent on temperature. For best results, gel electrophoresis must be run in a constant temperature. Sensitivity of SSCP is affected by $\mathrm{pH}$. Double-stranded DNA fragments are usually denatured by exposure to basic conditions: a high pH. Kukita et al ${ }^{24}$ found that adding glycerol to the polyacrylamide gel lowers the $\mathrm{pH}$ of the electrophoresis buffer--more specifically, the Tris-borate buffer and the result is increased SSCP sensitivity and clearer data. Fragment length also affects SSCP analysis. For optimal results, DNA fragment size should fall within the range of 150 to $300 \mathrm{bp}$, although SSCP analysis of RNA allows for a larger fragment size ${ }^{22 .}$ The presence of glycerol in the gel may also allow a larger DNA fragment size at acceptable sensitivity ${ }^{24}$.

Restriction digestion with restriction enzyme Ncol
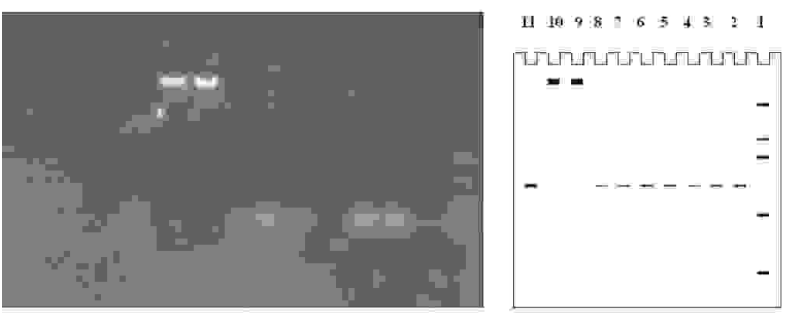

Figure 11: The $2 \%$ agarose gel was showing restriction digestion with restriction enzyme Nco1. Lane 1: DNA marker, Lane 2 sample 24, Lane 3: sample 16, Lane 4 sample 18, Lane 5: sample 22. Lane 6: sample 23, Lane 7. sample 30, Lane 8: sample 36, Lane 9:Chromosomal DNA digested with $L$ wel, Lane 10: Chromosomal undigested DNA, Lane 11: sample 22 amplified as control.

Under optimal conditions, approximately 80 to $90 \%$ of the potential base exchanges are detectable by SSCP 25(Wagner, 2002). SSCP $5.5 \%$ polyacrylamide gel was run for 3 hours at 150 volts (Figure 13). 1X TBE was added in buffer tank. DNA was run along with treated PCR products, which were treated in two ways 
one was only loaded with sucrose dye (by adding $4 \mu \mathrm{l}$ of PCR product along with $20 \mu$ l of loading dye) other samples were denatured. Denaturation was done by adding $4 \mu \mathrm{l}$ of PCR product along with $20 \mu$ l of loading dye (Formamide loading dye), followed by heating at $95{ }^{\circ} \mathrm{C}$ for 5 minutes and immediately placed on ice. Those diluted into sucrose gel-loading buffer was remained double stranded and serve as controls. In figure all controls were ok but the sample that was denatured showed that during denaturation and reannealing the shapes of DNA was changed but due to consistent changes in the temperature during running the gel caused problem. That's why there was smear appeared in denatured PCR products. In case of ACE there were less bands appeared but temperature also affects the denatured PCR product. In (Fig 12) all primers were completely utilized but in case of well 7, 13 and 15 primers appeared.

Single Stranded Conformational Polymorphism (Polyacrylamide Gel)

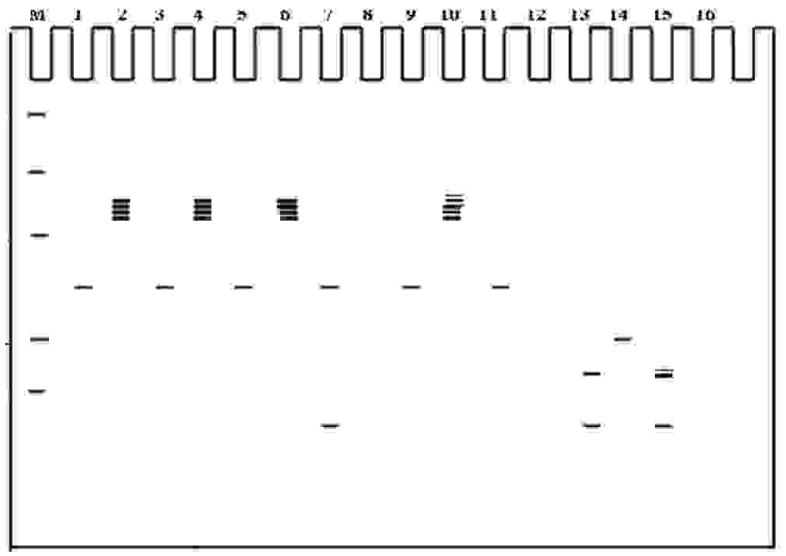

Fig-12. Analysis of M235T DNA polymorphism in the angitensinogen (AGT) gene and G2350A DNA polymorphism in the angiotensinogen converting enzyme (ACE) gene by $5.5 \%$ polyacrylamide gel electrophoresis. Following is the description of each slat of gel. Where " $G$ " stands for genomic DNA and " $D$ " for denatured DNA. Arrangement of samples in gel slot was as M: DNA marker, Lane 01: AGT01 G, Lane 02: AGT 01 D, Lane 03: AGT 03 G, Lane 04: AGT 03 D, Lane 05: AGT 04 G, Lane 06: AGT 04 D, Lane 07: AGT $07 \mathrm{G}$, Lane 08: AGT 07 D, Lane 09: AGT 08 G, Lane 10: AGT $08 \mathrm{D}$, Lane 11: AGT $22 \mathrm{G}$, Lane 12: AGT $22 \mathrm{D}$, Lane13: ACE $18 \mathrm{G}$, Lane 14: ACE 18 D, Lane 15; ACE $07 \mathrm{G}$. Lane 16: ACE $07 \mathrm{D}$.
The SSCP has been reported to lose sensitivity for mutation detection when the fragment size is above $300 \mathrm{bp}$ and the originator of the method suggested a maximum analysable size of $430 \mathrm{bp}^{17}$.

\section{REFERENCES}

1. Muldoon, M F. Rutan, G H. Defining hypertension: never as simple as it seems. J Hypertens. 2003; 21: 473-474.

2. Vollmer, W M. Sacks, F. M. Svetkey, L. P. New insights into the effects on blood pressure of diets low in salt and high in fruits and vegetables and low-fat dairy products. Curr Control Trials Cardiovasc Med. 2001; 2: 71-74.

3. Tanira, M.O. Balushi, KA. Genetic variations related to hypertension: a review. J Hum Hypertens.2005; 9:719.

4. Thiel, B. Weder, A. B. Genes for Essential Hypertension: Hype, Help, or Hope? J Clin Hypertens. 2000; 2:187-193.

5. Garcia, E. A. Newhouse, S. Caulfield, M. J. Munroe, P B Genes and hypertension. Curr Pharm Des. 2003; 9:1679-89.

6. Hideki, N. Takegoshi, K. Tanaka, K. Miyagi, K. Taira, S. Takayanagi, N. Successful Living Donor Liver Transplantation for Polycystic Liver in a Patient With Autosomal-dominant Polycystic Kidney Disease. J Clin Gastroenterol. 2001; 33:229-231.

Gorzelniak, K. Sharma, A M. Janke, J. Engeli, S. Luft, F

7.

C. Angiotensin Blockade Prevents Type 2 Diabetes by Formation of Fat Cells. Hypertension. 2002; 40:609-611.

8. Basset, B. P. Cecillon, S. Deprle, C. Thibaudin, D. Filippis, J.P. Alamartin, E. Berthou F. Hypertension after renal transplantation and polymorphism of genes involved in essential hypertension: ACE, AGT, AT1 R and ecNOS.: Clin Nephrol. 2002; 57:192.

Luft, F. C. Gross, V. Milia, A. F. Plehm R. Inagami T.

9.

Long-term blood pressure telemetry in AT2 receptordisrupted mice. J. Hypertens. 2000; 18:955-961.

10. Bantis, C. Ivens, K. Klein-Vehne, N. Grabensee, B. Einfluss genetischer Polymorphismen des Renin Angiotensin Systems auf die membranöse 
Glomerulonephritis. Nieren und Hochdruckkrankheiten. 2004; 4: 167-176.

11. Gareth, B. Gregory, Y. H.L. Eoin, O. B. ABC of hypertension The pathophysiology of hypertension Clinical review. BMJ. 2001; 322: 912-916.

Sambrook, J. Russel, W. D. Molecular Cloning: A

Labortatory Manual. Volume I-III. Cold Spring Harbor university Press, Cold Spring Harbor USA 2001.

13. Ponez, M. Solowiejezyk, D. Harpel, B. Construction of human gene libraries from small amount of pheripheral blood: Analysis of B like globin genes. Haemoglobin. 1982; 6:27.

14. Ana, N.A. Elizabeth, S. Richey, S. Calderon-Aranda, E. Ellen, S. 'Safe' levels of lead, cadmium. AHA Journal News report. 2004; 08/06/04.[LID 7385].

15. Laws, G.M. Stephen, P.A. Measurement of 8-OHdG in DNA by HLPC/EDC: The Importance of DNA Purity. BioTechniques. 1996; 20:28-36.

16. Manchester, K L. Value of A 260 /A 280 Ratios for Measuring Purity of Nucleic Acids. BioTechniques. 1993; 19:208.

17. Orita, M. Iwahana, H. Kanazawa, H. Hayashi, K. Sekiya, T. Detection of Polymorphisms of Human DNA by Gel Electrophoresis as SSCPs. Proceedings of the National Academy of Sciences of the United States of America. 1989; 86: 2766-70.
18. Warburg, O. Christian, W. Isolation and crystallization of enolase. Biochem. Z. 1942; 310:384-421.

19. Glasel, J.A. Validity of Nucleic Acid Purities Monitored by $260 \mathrm{~nm} / 280 \mathrm{~nm}$. Absorbance Ratios. BioTechniques. 1995; 18:62-63.

20. Wilfinger, W.W. Mackey, M. Chanczynski, P. Effect of $\mathrm{pH}$ and lonic Strength on the Spectrophotometric Assessment of Nucleic Acid Purity. BioTechniques. 1997; 22: 474-480.

21. Laragh, J.H. Sealey, J.E. K+ Depletion and the Progression of Hypertensive Disease or Heart Failure: The Pathogenic Role of Diuretic-Induced Aldosterone Secretion. Hypertension. 2001; 27: 806810.

22. Wagner, T. Muhr, D. Oefner, P.J. Polymerase chain reaction fidelity and denaturing high-performance liquid chromatography. J Chromatogr B Analyt Technol Biomed Life Sci. 2002; 782:105-10.

23. Yang-Cao, T. Yuanyuan, Z. Baishan, F. Optimization of polymerase chain reaction-amplified conditions using the uniform design method. J. Chemical Technology \& Biotechnology. 2004; 79: 910-913.

24. Kukita, Y. Tahira, T. Sommer, S. Hayashi, K. SSCP Analysis of Long DNA Fragments in Low pH Gel. Human Mutation. 1997; 10: 400-7.

\section{DREAM AND STRUGGLE DREAMS ALWAYS COME TRUE}

Shuja Tahir 